\title{
FLUKTUASI KURS VALUTA ASING DI BEBERAPA NEGARA ASIA TENGGARA
}

\author{
Josephine Wuri \\ Dosen Program Studi Akuntansi, Fakultas Ekonomi, Universitas Sanata Dharma \\ (josephine@usd.ac.id)
}

DOI: doi.org/10.24071/exero.2018.010101

\begin{abstract}
Recently, the fluctuation of trade among countries in Southeast Asia is very fast, especially with the agreement of the Asean Economic Community (AEC) in 2015. It will establish the economic integration in Southeast Asia. This is expected to reduce the gap among the ASEAN countries. Therefore, the trade among countries also raises the fluctuation of foreign exchange rates. This study aims to analyze the factors that influence foreign exchange rates in several Southeast Asian countries. The secondary data used in this research were taken from the International Financial Statistics published by the International Monetary Fund 2012-2014. The data analysis technique used in this research was panel data regression analysis with Fixed Effect Model. The results showed that inflation and interest rates were variables that affect foreign exchange rates in several Southeast Asian countries. It was known that inflation and interest rates had positive effect on foreign exchange rates. It is also known that the depreciation of rupiah against US dollar was the highest compared to the ones of Ringgit Malaysia and Bath Thailand. Furthermore, the study is expected to give suggestion and information for government in those countries in determining monetary policy to overcome the fluctuation of foreign exchange rates.
\end{abstract}

Keywords: exchange rate, inflation, interest rate, fixed effect model

\section{PENDAHULUAN}

Perkembangan perdagangan antar negara di Asia Tenggara sangat pesat akhir-akhir ini, terlebih dengan adanya kesepakatan Asean Economic Community (AEC), yang akan membentuk integrasi ekonomi di kawasan Asia Tenggara. Adanya AEC diharapkan dapat meningkatkan daya saing dan dapat menarik investor asing, selain itu dapat meningkatkan perdagangan setiap negara anggota, pembenahan sistem finansial, dan dapat membantu negara-negara yang terlambat pertumbuhannya. AEC memungkinkan satu negara menjual barang dan jasa dengan mudah ke negara-negara lain di seluruh Asia Tenggara. Manfaat lain AEC yaitu dapat menciptakan lapangan kerja baru, sehingga dapat meningkatkan kesejahteraan masyarakat yang hidup di Asia Tenggara. Selain itu dapat memperkecil kesenjangan antara negara-negara ASEAN dalam hal pertumbuhan perekonomian dengan meningkatkan ketergantungan anggota-anggota didalamnya (Baskoro, 2014). 
Hambatan perdagangan akan cenderung berkurang bahkan menjadi tidak ada. Hal tersebut akan berdampak pada peningkatan eskpor yang pada akhirnya akan meningkatkan Gross Domestic Product (GDP) Indonesia.

Pada sisi investasi, kondisi ini dapat menciptakan iklim yang mendukung masuknya Foreign Direct Investment (FDI) yang dapat menstimulus pertumbuhan ekonomi melalui perkembangan teknologi, penciptaan lapangan kerja, pengembangan sumber daya manusia (human capital) dan akses yang lebih mudah kepada pasar dunia (Hew, 2003). Dari aspek ketenagakerjaan, terdapat kesempatan yang sangat besar bagi para pencari kerja karena dapat banyak tersedia lapangan kerja dengan berbagai kebutuhan akan keahlian yang beraneka ragam. Selain itu, akses untuk pergi keluar negeri dalam rangka mencari pekerjaan menjadi lebih mudah bahkan bisa jadi tanpa ada hambatan tertentu. AEC juga menjadi kesempatan yang bagus bagi para wirausahawan untuk mencari pekerja terbaik sesuai dengan kriteria yang diinginkan. Dalam hal ini dapat memunculkan risiko ketenagakerjaan bagi Indonesia. Dilihat dari sisi pendidikan dan produktivitas Indonesia masih kalah bersaing dengan tenaga kerja yang berasal dari Malaysia, Singapura, dan Thailand (Baskoro, 2014).

Oleh karena perdagangan antar negara berkaitan dengan pembayaran antar negara yang mana mata uangnya juga berbeda, maka hal ini juga menimbulkan masalah kurs valuta asing yang berfluktuasi. Jika suatu negara menganut sistem kurs bebas, nilai mata uang suatu negara mudah untuk berfluktuasi sesuai dengan kondisi perekonomian yang terjadi saat itu. Nilai mata uang yang lemah akan meningkatkan ekspor dan membuat impor lebih mahal, sehingga mengurangi defisit perdagangan suatu negara (atau meningkatkan surplus) dari waktu ke waktu. Sebaliknya, mata uang yang menguat secara signifikan dapat mengurangi daya saing ekspor dan membuat impor lebih murah, yang dapat menyebabkan defisit perdagangan akan terus berlanjut. Hal ini sejalan dengan hasil penelitian Miskhin (2001) yang menyebutkan salah satu faktor penentu fluktuasi kurs adalah kondisi neraca perdagangan suatu negara. Sedangkan jika suatu negara menganut sistem kurs tetap, volatilitas mata uang tersebut cenderung rendah seperti yang dijelaskan dalam penelitian Yanxiang Gu (2009). 
Selain karena tingginya aktivitas perdagangan antar negara, fluktuasi kurs mata uang sejumlah negara Asia juga disebabkan karena adanya perbaikan perekonomian Amerika Serikat (AS) yang memicu kekhawatiran adanya pemangkasan lanjutan program stimulus The Federal Reserves. Data yang dipublikasikan Blommberg pada Mei 2015 nilai tukar Rupiah terhadap dolar Amerika terdepresiasi sebesar 27\%, paling besar dibandingkan negara-negara Asia Tenggara lainnya. Diikuti mata uang Ringgit yang terdepresiasi sebesar 14,2\%, kemudian Peso Phillipina terdepresiasi sebesar 9\%, diikuti Dolar Singapura terdepresiasi sebesar 8,2\% kemudian Bath Thailand terdepresiasi sebesar 7,6\%.

Sebuah negara perlu memiliki mata uang yang relatif stabil untuk menarik modal investasi dari investor asing. Krisis Asia tahun 1997-1998 ditandai dengan adanya devaluasi Baht Thailand pada bulan Juli 1997 memaksa bank sentral Thailand untuk bergantung terhadap dolar AS dan membiarkan mata uangnya tidak stabil. Hal ini memicu keruntuhan finansial yang menyebar ke ekonomi tetangga seperti Indonesia, Malaysia, Korea Selatan dan Hongkong. Dampak selanjutnya menyebabkan kebangkrutan di negara-negara tersebut dan pasar saham jatuh. Nilai Yuan Tiongkok stabil selama satu dekade yaitu 1994-2004, yang memungkinkan ekspornya meningkat. Hal ini menimbukan banyak keluhan dari AS dan negaranegara lain bahwa Tiongkok secara sengaja menekan nilai mata uangnya untuk meningkatkan ekspor. Hingga saat ini Tiongkok berusaha keras agas mata uangnya reminbi bisa diterima sebagai mata uang tetap IMF sebagai salah satu Special Drawing Rights, dan pada November 2015 telah diputuskan bahwa reminbi bisa menjadi mata uang internasional mulai 2016. Hal ini akan membuka kesempatan bagi negara-negara di dunia untuk menggunakan mata uang reminbi dalam kegiatan perdagangan dan investasi.

Tantangan yang dihadapi oleh Indonesia memasuki integrasi ekonomi ASEAN tidak hanya yang bersifat internal di dalam negeri tetapi terlebih lagi persaingan dengan negara sesama ASEAN dan negara lain di luar ASEAN seperti Tiongkok dan India. Hal ini merupakan tantangan yang sangat serius ke depan karena telah mengakibatkan neraca perdagangan Indonesia yang defisit terhadap beberapa negara ASEAN tersebut. Ancaman yang diperkirakan lebih serius lagi adalah perdagangan bebas ASEAN dengan Tiongkok. Tantangan lainnya adalah laju 
inflasi Indonesia yang masih tergolong tinggi bila dibandingkan dengan negara lain di kawasan ASEAN. Stabilitas makro masih menjadi kendala peningkatan daya saing Indonesia dan tingkat kemakmuran Indonesia juga masih lebih rendah dibandingkan negara lain. Populasi Indonesia yang terbesar di ASEAN membawa konsekuensi tersendiri bagi pemerataan pendapatan (Andini, 2014).

Dampak globalisasi ekonomi dan finansial di negara-negara Asia Tenggara secara tidak langsung juga dirasakan oleh para pelaku usaha baik di perusahaan tingkat mikro, kecil, maupun menengah baik nasional maupun multinasional. Ketidakpastian akan tinggi rendahnya kurs valuta asing akan mempengaruhi perhitungan biaya produksi dan perencanaan pengelolaan anggaran mereka. Berdasarkan latar belakang masalah di atas, peneliti tertarik untuk mengetahui faktor-faktor apa saja yang mempengaruhi kurs valuta asing di beberapa negara Asia Tenggara. Hasil penelitian ini diharapkan sebagai bahan masukan dan informasi bagi pemerintah dan para pembuat kebijakan di bidang moneter agar dapat mengatasi gejolak kurs valuta asing.

Selanjutnya konsep kurs valuta asing merupakan perbandingan nilai atau harga dua mata uang yang berbeda. Kurs valuta asing adalah harga valuta asing yang dinyatakan dalam mata uang sendiri, misal US \$ $1=\mathrm{Rp} 13.700,00$. Dalam sistem pasar bebas, kurs valuta asing ditentukan oleh permintaan dan penawaran valuta asing yang terjadi di pasar valuta asing. Kurs berfluktuasi setiap saat sesuai dengan permintaan dan penawaran yang terjadi di pasar valuta asing. Hal ini bisa terjadi karena adanya transaksi perdagangan antar negara. Sebuah mata uang akan mengalami penguatan atau pelemahan terhadap mata uang lainnya. Mata uang yang mengalami penguatan relatif terhadap mata uang lainnya dinyatakan sebagai mata uang yang terapresiasi. Sedangkan mata uang yang nilainya turun terhadap mata uang lain disebut mata uang yang mengalami depresiasi (Miskhin, 2001). Konsekuensinya adalah harga barang-barang yang dijual ke luar negeri menjadi lebih murah dan harga barang-barang impor menjadi lebih mahal di dalam negeri.

Permintaan valuta asing berasal dari para importir yang memerlukan devisa untuk membayar impor barang/jasa dari luar negeri, pihak-pihak yang membayar utang, serta pihak-pihak yang memberikan atau mengirimkan uang. Para importir membutuhkan valuta asing untuk membiayai pembelian barang-barang impor 
mereka. Selain itu, permintaan valuta asing juga digunakan pemerintah, perusahaan, serta individu untuk membayar angsuran pinjaman beserta bunganya. Valuta asing juga dibutuhkan oleh orang yang ingin mengirimkan uang kepada pihak lain.

Supply valuta asing berasal dari para eksportir, pihak-pihak yang menerima pinjaman, serta pihak-pihak yang mendapatkan kiriman uang. Perusahaan atau eksportir yang menerima pembayaran dari luar negeri dalam hal tertentu harus melakukan pembayaran di dalam negeri dalam bentuk mata uang dalam negeri. Hal ini dilakukan dengan cara perusahaan tersebut harus menukarkan atau menjual valuta asing yang diterimanya terhadap mata uang dalam negeri. Pemerintah, perusahaan, maupun individu seringkali mendapatkan bantuan maupun pinjaman dari luar negeri dalam bentuk mata uang asing. Bantuan atau pinjaman ini harus dikonversikan ke dalam mata uang dalam negeri apabila akan dipergunakan sebagai alat pembayaran transaksi di dalam negeri. Apabila permintaan terhadap suatu mata uang, misal permintaan terhadap Dolar Amerika lebih tinggi dari penawarannya, maka nilai Dolar Amerika akan naik, begitu pula sebaliknya. Kurs terbentuk ketika jumlah dan kurs yang diminta sama dengan jumlah dan kurs mata yang ditawarkan. Kondisi ini disebut sebagai kondisi keseimbangan kurs (di titik E).

Meningkatnya permintaan Dollar Amerika tidak hanya disebabkan oleh transaksi Rupiah yang dipertukarkan dengan Dollar Amerika, namun disebabkan juga oleh transaksi Yen Jepang yang dipertukarkan dengan Dollar Amerika, Poundsterling Inggris yang dipertukarkan dengan Dollar Amerika, dan mata uang asing lainnya yang dipertukarkan dengan Dollar Amerika. Begitupun sebaliknya, meningkatnya penawaran Dollar Amerika tidak hanya disebabkan oleh transaksi Dollar Amerika yang dipertukarkan dengan Rupiah, namun disebabkan juga oleh transaksi Dollar Amerika yang dipertukarkan dengan Yen Jepang, Dollar Amerika yang dipertukarkan dengan Poundsterling Inggris dan Dollar Amerika yang dipertukarkan dengan mata uang asing lainnya.

Pasar valuta asing atau sering disebut foreign exchange market atau pasar mata uang asing atau bursa valuta asing merupakan suatu tempat yang menyelenggarakan kegiatan pertukaran mata uang dari berbagai negara. Aktivitas perdagangan mata uang asing ini melibatkan pusat keuangan utama dunia. Transaksi berlangsung selama 24 jam secara berkesinambungan. Berakhirnya perdagangan di 
suatu negara akan diikuti dengan dibukanya perdagangan di negara lain. Perdagangan mata uang asing tidak pernah berhenti selama jam kerja dunia masih buka. Pusat-pusat keuangan dunia berintegrasi secara bersama-sama membentuk pasar valuta asing dunia. Keterpaduan antar pusat keuangan dunia didukung oleh teknologi jaringan komunikasi yang mampu memberikan fasilitas untuk terlaksananya perdagangan secara cepat dan efisien.

Sifat kurs dibedakan menjadi dua, yaitu volatile dan vis a vis. Kurs dikatakan volatile jika kurs tersebut peka untuk bergerak. Harga valuta asing mudah untuk naik atau turun tergantung dari kondisi perekonomian suatu negara. Kenaikan (penurunan) harga valuta asing disebut apresiasi (depresiasi) jika penyebabnya adalah kekuatan pasar, sedangkan disebut revaluasi (devaluasi) jika penyebabnya adalah kebijakan pemerintah. Kurs yang relatif stabil lebih dikenal dengan istilah "hard currency", sedangkan kurs yang tidak stabil dikenal dengan istilah "soft currency". Sebagai akibat adanya sifat kurs yang volatile ini, timbul tiga macam bisnis, yaitu hedging (pelaku lebih menyukai menghindari fluktuasi kurs), spekulasi (pelaku lebih menyukai fluktuasi kurs), dan arbitrase (pelaku yang mengambil keuntungan dengan adanya perbedaan harga asset finansial, perbedaan kurs, serta perbedaan tingkat bunga antar negara. Di sisi lain, kurs dikatakan vis a vis jika kurs tersebut dinyatakan berhadapan. Misalnya, Rp 13.700 per US\$ sama dengan US\$ 1/13.700 per Rupiah. Oleh karena kurs memiliki sifat vis a vis, maka jika kurs valuta asing mengalami apresiasi terhadap mata uang dalam negeri, berarti kurs mata uang dalam negeri mengalami depresiasi.

Pada dasarnya sistem penentuan kurs dibedakan menjadi tiga jenis (Camarazza dan Aziz, 1997) yaitu (1) Kurs Tetap (Fixed Exchange Rate), (2) Kurs Bebas (Floating Exchange Rate), (3) Kurs Mengambang Terkendali (Managed Floating Exchange Rate). Pada sistem kurs tetap nilai tukar valas dikaitkan dengan emas/ mata uang kuat sebagai standar/patokannya. Dalam hal ini pemerintah menjamin berapapun jumlah valas/mata uang kuat yang diminta oleh pasar. Pada sistem kurs bebas, kurs valuta asing bergerak bebas sesuai dengan permintaan dan penawaran valas di bursa-bursa internasional. Dalam kaitan ini ada dua pengertian yaitu clean float (pemerintah tidak campur tangan) dan dirty float (pemerintah masih ikut campur tangan). Dalam sistem kurs mengambang terkendali, kurs ditetapkan 
dalam batas-batas tertentu (band intervention) dan juga ditentukan oleh campur tangan pemerintah. Sistem ini digunakan Indonesia sejak sebelum krisis sampai masa krisis tahun 1997. Sejak bulan September 1997 sistem kurs diambangkan secara bebas sampai saat ini. Volatilitas kurs valuta asing tergantung pada sistem kurs yang digunakan dan kemungkinan adanya monetary schock (Benigno, 2000).

Ada beberapa faktor yang dapat mempengaruhi kurs valuta asing (Miskhin, 2001), yaitu (1) tingkat inflasi (2) nilai ekspor dan impor barang (3) suku bunga (4) tarif dan kuota (trade barriers), serta (5) produktivitas. Menurut teori Puchasing Power Parity (PPP), dalam jangka panjang jika harga barang-barang di Indonesia meningkat, relatif terhadap harga barang-barang dari luar negeri maka akan mengakibatkan Rupiah cenderung terdepresiasi dan sebaliknya jika harga barangbarang di Indonesia turun maka Rupiah cenderung mengalami apresiasi. Adanya peningkatan permintaan ekspor akan mengakibatkan nilai mata uang negara tersebut mengalami apresiasi, dan sebaliknya peningkatan permintaan impor mengakibatkan nilai mata uang mengalami depresiasi. Jika suku bunga dalam negeri relatif lebih tinggi dibandingkan negara lain, maka nilai mata uang negara tersebut akan mengalami apresiasi. Hal ini disebabkan karena suku bunga yang tinggi akan menarik bagi para investor asing, sehingga mereka tertarik untuk menanamkan modalnya di negara tersebut, sehingga permintaan mata uang negara tersebut meningkat dan selanjutnya akan mengalami apresiasi. Adanya penetapan tarif atau kuota (trade barriers) terhadap barang dari negara lain akan meningkatkan permintaan barang yang sama dari negara tersebut. Hal ini mengakibatkan nilai mata uang negara tersebut mengalami apresiasi. Jadi peningkatan trade barriers dalam jangka panjang akan mengakibatkan nilai mata uang suatu negara mengalami apresiasi. Jika suatu negara menjadi lebih produktif dibandingkan negara lain, harga barang-barang di dalam negeri akan turun dan tetap ada keuntungan. Hal ini akan mengakibatkan peningkatan permintaan akan barang-barang dalam negeri dan selanjutnya akan meningkatkan mata uang negara tersebut mengalami apresiasi.

Sedangkan pendekatan moneter berkeyakinan bahwa faktor-faktor yang melandasi fungsi permintaan dan penawaran uang merupakan penjelas utama pergerakan kurs valuta asing. Menurut pendekatan ini, kurs valuta asing ditentukan oleh jumlah uang beredar, pendapatan, serta suku bunga. Penelitian ini membatasi 
ada faktor yang mempengaruhi kurs valuta asing adalah tingkat inflasi dan suku bunga.

Menurut teori Puchasing Power Parity (PPP), dalam jangka panjang jika harga barang-barang di Indonesia meningkat, relatif terhadap harga barang-barang dari luar negeri maka akan mengakibatkan Rupiah cenderung terdepresiasi dan sebaliknya jika harga barang-barang di Indonesia turun maka Rupiah cenderung mengalami apresiasi. Jika suatu negara menjadi lebih produktif dibandingkan negara lain, harga barang-barang di dalam negeri akan turun dan tetap ada keuntungan. Hal ini akan mengakibatkan peningkatan permintaan akan barang-barang dalam negeri dan selanjutnya akan meningkatkan mata uang negara tersebut mengalami apresiasi. Sehubungan dengan hal tersebut, maka hipotesis yang diajukan adalah:

\section{H1: Tingkat inflasi berpengaruh terhadap kurs valuta asing}

Jika suku bunga domestik relatif lebih tinggi dibandingkan negara lain, maka nilai mata uang negara tersebut akan mengalami apresiasi. Hal ini disebabkan karena suku bunga yang tinggi akan menarik bagi para investor asing, sehingga mereka tertarik untuk menanamkan modalnya di negara tersebut, sehingga permintaan mata uang negara tersebut meningkat dan selanjutnya akan mengalami apresiasi. Maka hipotesis yang diajukan adalah:

\section{H2: Suku bunga domestik berpengaruh terhadap kurs vakuta asing}

\section{METODE PENELITIAN}

\section{Desain Penelitian}

Kestabilan kurs valuta asing adalah sesuatu yang penting untuk menciptakan kondisi ekonomi yang kondusif agar tercipta keberlangsungan usaha yang dapat meningkatkan pertumbuhan ekonomi suatu negara. Banyak faktor yang mempengaruhi tinggi rendahnya kurs valuta asing, dalam penelitian ini kurs valuta asing ditentukan oleh variabel tingkat inflasi dan suku bunga (Miskhin, 2001) digambarkan dalam kerangka pemikiran sebagai berikut:

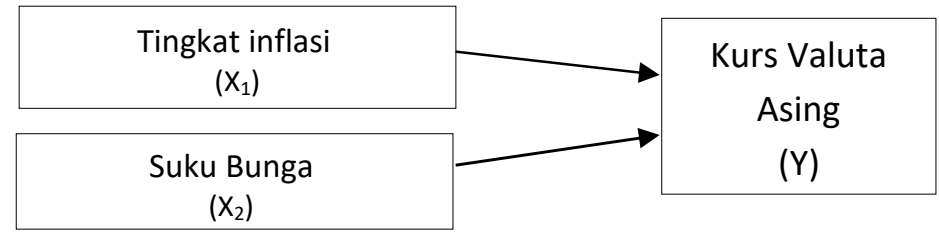

Gambar 1. Kerangka Pemikiran 


\section{Jenis Penelitian}

Jenis penelitian yang digunakan adalah studi empiris, yaitu penelitian yang dilakukan berdasarkan data eksperimental hasil dari pengamatan, pengalaman. Studi empiris melibatkan sampel lebih banyak dan jangka waktu yang panjang, studi empiris bertujuan unuk mencari generalisasi atas suatu pertanyaan yang berhubungan dengan suatu subyek.

\section{Subyek dan Obyek Penelitian}

Subyek penelitian adalah orang-orang dan badan yang berhubungan dengan obyek penelitian. Subyek dalam penelitian ini adalah lembaga-lembaga pemerintah yang telah mengumpulkan data variabel ekonomi makro dalam penelitian ini adalah International Monetary Fund (IMF). Sedangkan obyek penelitian adalah hal-hal yang ingin diteliti oleh peneliti. Obyek dalam penelitian ini adalah faktor-faktor yang mempengaruhi kurs valuta asing

\section{Teknik Pengumpulan Data}

Teknik pengumpulan data yang dipakai dalam penelitian ini menggunakan studi dokumentasi (Library Research) yaitu mengumpulkan data dari sumber-sumber yang berasal dari instansi-instansi/ lembaga-lembaga pemerintah. Data yang digunakan merupakan data sekunder yang diperoleh dari International Financial Statistics, yang diterbitkan oleh International Monetary Fund (IMF). Data yang digunakan adalah data bulanan mulai tahun 2012-2014.

\section{Populasi dan Sampel Penelitian}

Populasi adalah wilayah generalisasi yang terdiri atas obyek/subyek yang mempunyai kualitas dan karakteristik tertentu yang ditetapkan oleh peneliti untuk dipelajari dan kemudian ditarik kesimpulannya (Sugiyono, 2009). Populasi dalam penelitian ini adalah seluruh negara Asia Tenggara. Sedangkan sampel adalah bagian dari jumlah dan karakteristik yang dimiliki oleh populasi tersebut. Sampel yang digunakan dalam penelitian ini adalah sebagian dari negara-negara di Asia Tenggara, yaitu Indonesia, Malaysia, dan Thailand. Teknik pengambilan sampel dalam penelitian ini dengan teknik penarikan sampel probability sampling yaitu menggunakan metode random sampling. 


\section{Variabel Penelitian dan Definisi Operasional}

Variabel penelitian adalah suatu besaran yang dapat berubah, sehingga mempengaruhi hasil penelitian. Variabel membentuk apa saja yang ditetapkan oleh peneliti untuk dipelajari sehingga diperoleh informasi tentang hal tersebut kemudian ditarik kesimpulannya (Sugiyono, 2008). Variabel-variabel dalam penelitian ini adalah: (1) Variabel Bebas (Independent Variable) meliputi variabel inflasi dan suku bunga. Tingkat inflasi adalah suatu proses meningkatnya harga-harga secara umum dan terus-menerus (kontinu) berkaitan dengan mekanisme pasar yang dapat disebabkan oleh berbagai faktor, antara lain, konsumsi masyarakat yang meningkat, berlebihnya likuiditas di pasar yang memicu konsumsi atau bahkan spekulasi, selain itu juga karena adanya ketidaklancaran distribusi barang. Inflasi dalam penelitian ini diukur dari indeks harga konsumen (Consumer price index) dengan tahun dasar tahun 2010. Sedangkan suku bunga adalah harga dari uang. Dalam penelitian ini pengukuran suku bunga diperoleh dari tingkat suku bunga deposito pertahun (dalam prosentase). (2) Variabel Terikat (Dependent Variable) yaitu kurs valuta asing. Kurs valuta asing adalah perbandingan nilai mata uang asing dinyatakan dalam mata uang sendiri. Pengukuran kurs valuta asing yang digunakan untuk negara Indonesia adalah kurs tengah nilai mata uang Rupiah per US dollar. Untuk negara Malaysia adalah kurs tengah nilai mata uang Ringgit per US dollar. Sedangkan untuk negara Thailand adalah kurs tengah nilai mata uang Bath per US dollar.

\section{Alat Analisis}

Untuk menjawab tujuan penelitian mengenai faktor-faktor yang mempengaruhi kurs valuta asing digunakan alat analisis Regresi Data Panel karena jenis data yang digunakan dalam penelitian ini ada data panel yang merupakan gabungan antara data time series dan cross section. Penggunaan analisis regresi data panel memerlukan uji asumsi klasik sehingga persamaan garis regresi yang diperoleh benar-benar dapat digunakan untuk memprediksi variabel dependen. Uji asumsi klasik meliputi (Ghozali, 2006): uji normalitas, uji multikolinieritas, uji heteroskedastisitas, uji autokorelasi. Setelah seluruh pengujian asumsi klasik terpenuhi, maka dilakukan analisis data dengan menggunakan Analisis Regresi Data Panel. Analisis regresi data panel adalah regresi dengan data yang memiliki dimensi waktu dan dimensi ruang. Manfaat menggunakan regresi data panel adalah: (1) 
Dengan menggabungkan data time series dan cross section, data panel menyediakan data yang lebih banyak dan informasi yang lebih lengkap serta bervariasi dan kolinieritas (multikolinearitas) antara data semakin berkurang. Dengan demikian akan dihasilkan degree of freedom (derajat kebebasan) yang lebih besar sehingga dapat diperoleh hasil estimasi yang lebih efisien. (2) Data panel mampu mengakomodasi tingkat heterogenitas individu-individu yang tidak diobservasi namun dapat mempengaruhi hasil dari permodelan (individual heterogeneity). Hal ini tidak dapat dilakukan oleh studi time series maupun cross section sehingga dapat menyebabkan hasil yang diperoleh melalui kedua studi ini akan menjadi bias. (3) Data panel dapat digunakan untuk mempelajari kedinamisan data. Artinya dapat digunakan untuk memperoleh informasi bagaimana kondisi individu-individu pada waktu tertentu dibandingkan pada kondisinya pada waktu yang lainnya. (4) Data panel dapat mengidentifikasikan dan mengukur efek yang tidak dapat ditangkap oleh data cross section murni maupun data time series murni. (5) Data panel memungkinkan untuk membangun dan menguji model yang bersifat lebih rumit dibandingkan data cross section murni maupun data time series murni. (6) Menggabungkan informasi dari data time series dan cross section dapat mengatasi masalah yang timbul ketika ada masalah penghilangan variabel (ommited-variabel). Dalam regresi data panel dilakukan regresi dengan data cross-section dan juga data time series, dengan Fixed Effect Model (Gujarati, 2008). Adapun rumus dari regresi data panel adalah:

$$
\mathrm{KURS}=\alpha_{1}+\alpha_{2} \mathrm{D}_{2 \mathrm{i}}+\alpha_{3} \mathrm{D}_{3 \mathrm{i}}+\beta_{1} \mathrm{INF}+\beta_{2} \mathrm{SB}+e
$$

Keterangan :

$\alpha_{1} \quad$ : Intersep (konstanta) negara pembanding

$\mathrm{D}_{2} \ldots \mathrm{D}_{3}$ : Dummy Variabel untuk 2 negara sedangkan sisanya, satu negara $\left(D_{1}\right)$ dipakai sebagai sebagai negara pembanding (bebas untuk memilih negara mana sebagai negara pembanding)

$\beta_{1-}-\beta_{2}$ : Koefisien Regresi

KURS: Nilai Tukar Mata Uang

INF : Inflasi

SB : Suku Bunga

$\boldsymbol{e}$ : Error Term 


\section{HASIL ANALISIS DAN PEMBAHASAN}

Untuk menjawab tujuan penelitian yaitu mengetahui faktor-faktor apa saja yang mempengaruhi kurs valuta asing di beberapa negara Asia Tenggara digunakan analisis regresi data panel dengan Fixed Effect Model. Agar persamaan garis regresi yang diperoleh benar-benar dapat digunakan untuk memprediksi variabel dependen, sebelumnya perlu dilakukan uji asumsi klasik. Uji asumsi klasik adalah pengujian asumsi-asumsi statistik yang harus dipenuhi pada analisis regresi linier yang berbasis Ordinary Least Square (OLS). Dari hasil uji validitas dan reliabilitas dapat disimpulkan bahwa semua instrumen yang digunakan adalah valid dan reliabel.

\section{Analisis Data}

Data penelitian merupakan data sekunder yang berasal dari International Financial Statistics yang diterbitkan oleh IMF, yaitu data mengenai kurs valuta asing, inflasi, dan suku bunga dari bulan Januari tahun 2012 sampai dengan bulan Desember tahun 2014 seperti terlihat pada lampiran.

\section{Kurs Valuta Asing}

Sejak diberlakukannya sistem kurs bebas (free float exchange rate), pergerakan kurs bisa seringkali berubah. Faktor yang mempengaruhinya selain faktor fundamental ekonomi, juga faktor non ekonomi suatu negara.

\section{Tabel 1. Rata-rata Perkembangan Kurs Mata Uang terhadap Dolar Amerika}

\begin{tabular}{|c|c|c|c|}
\hline \multirow{2}{*}{ Tahun } & \multicolumn{3}{|c|}{ Rata-rata Kurs Valuta Asing } \\
\cline { 2 - 4 } & $\begin{array}{c}\text { Rupiah } \\
\text { Indonesia }\end{array}$ & $\begin{array}{c}\text { Ringgit } \\
\text { Malaysia }\end{array}$ & $\begin{array}{c}\text { Bath } \\
\text { Thailand }\end{array}$ \\
\hline 2012 & 9387,00 & 3,09 & 31,08 \\
\hline 2013 & 10469,25 & 3,15 & 30,73 \\
\hline 2014 & 11865,23 & 3,27 & 32,48 \\
\hline
\end{tabular}

Sumber: Data diolah

Dari tabel 1. di atas terlihat pergerakan mata uang suatu negara yang cenderung melemah terhadap dolar AS. Nilai tukar Rupiah terhadap dolar AS pada tahun 2012 rata-rata sebesar Rp 9387 per dolar yang terus melemah 11,53\% menjadi sebesar Rp 10.469,25 per dolar pada 2013 dan melemah kembali 14,29 persen menjadi Rp 11.865,23 per dolar pada periode 2014. Hal ini masih terus berlanjut di tahun 2015 yang mencapai kisaran Rp 13.700 per dolar, melemah sebesar 45,9 persen dibandingkan kondisi tahun 2012. Faktor yang menyebabkannya diawali krisis ekonomi global yang dimulai sekitar tahun 2009. 
Nilai tukar Ringgit terhadap dolar AS pada tahun 2012 rata-rata sebesar MYR 3,09 per dolar yang terus melemah 1,94\% menjadi sebesar MYR 3,15 per dolar pada 2013 dan melemah kembali 3,8 persen menjadi MYR 3,27 per dolar pada periode 2014. Hal ini masih terus berlanjut di tahun 2015 yang mencapai kisaran MYR 4,24 per dolar, melemah sebesar 37,22 persen dibandingkan kondisi tahun 2012.

Nilai tukar Bath terhadap dolar AS cenderung berfluktuasi, pada tahun 2012 rata-rata sebesar THB31,08 per dolar yang terlihat menguat $1,13 \%$ menjadi sebesar THB30,73 per dolar pada 2013 dan kemudian melemah kembali 5,7 persen menjadi THB32,48 per dolar pada periode 2014. Hal ini masih terus berlanjut di tahun 2015 yang mencapai kisaran THB36,06 per dolar, melemah sebesar 11,02 persen dibandingkan kondisi tahun 2012.

\section{Inflasi}

Dari tabel 2. di bawah terlihat bahwa rata-rata tingkat inflasi di Indonesia lebih tinggi dibandingkan negara Malaysia dan Thailand. Angka inflasi yang diukur dari Consumer Price Index (CPI) Indonesia tahun 2012 sebesar 112 persen meningkat sebesar 11,35 persen menjadi 124,71 persen di tahun 2014. CPI Malaysia tahun 2012 sebesar 104,9 persen meningkat sebesar 5,34 persen menjadi 110,5 persen di tahun 2014. Sedangkan CPI Thailand tahun 2012 sebesar 107,47 persen meningkat sebesar 3,74 persen menjadi sebesar 111,49 persen di tahun 2014. Dari data tersebut terlihat bahwa peningkatan inflasi di Indonesia paling tinggi kemudian diikuti Malaysia dan Thailand.

Tabel 2. Rata-rata Perkembangan Tingkat Inflasi

\begin{tabular}{|c|c|c|c|}
\hline \multirow{2}{*}{ Tahun } & \multicolumn{3}{|c|}{ Rata-rata Inflasi } \\
\cline { 2 - 4 } & Indonesia & Malaysia & Thailand \\
\hline 2012 & 112 & 104,9 & 107,47 \\
\hline 2013 & 119,75 & 107,14 & 109,81 \\
\hline 2014 & 124,71 & 110,5 & 111,49 \\
\hline
\end{tabular}

Sumber: Data diolah

Laju inflasi Indonesia yang masih tergolong tinggi bila dibandingkan dengan negara lain di kawasan ASEAN. Stabilitas makro masih menjadi kendala peningkatan daya saing Indonesia. 


\section{Suku Bunga}

Dari tabel 3. di bawah terlihat bahwa rata-rata suku bunga di Indonesia lebih tinggi dibandingkan negara Malaysia dan Thailand. Angka suku bunga Indonesia tahun 2012 sebesar 6 persen meningkat sebesar 5 persen menjadi 6,30 persen di tahun 2013. Angka ini kembali meningkat sebesar 36,9 persen menjadi 8,63 persen di tahun 2014. Suku bunga Malaysia tahun 2012 sebesar 3 persen menurun sebesar 1 persen menjadi 2,97 persen di tahun 2013. Suku bunga Malaysia meningkat kembali dari 2,39 persen menjadi sebesar 3,05 persen pada tahun 2014 .

\section{Tabel 3. Rata-rata Perkembangan Tingkat Suku Bunga}

\begin{tabular}{|c|c|c|c|}
\hline \multirow{2}{*}{ Tahun } & \multicolumn{3}{|c|}{ Rata-rata Suku Bunga (\%) } \\
\cline { 2 - 4 } & Indonesia & Malaysia & Thailand \\
\hline 2012 & 6 & 3 & 2,8 \\
\hline 2013 & 6,3 & 2,97 & 2,88 \\
\hline 2014 & 8,63 & 3,05 & 1,96 \\
\hline
\end{tabular}

Suku bunga Thailand tahun 2012 paling rendah diantara negara yang lain yaitu sebesar 2,80 persen yang kemudian meningkat sebesar 2,86 persen menjadi sebesar 2,88 persen di tahun 2013. Pada tahun 2014, suku bunga di Thailand turun cukup tajam yaitu sebesar 31,94 persen.

Dari data tersebut terlihat bahwa suku bunga di Indonesia terlihat paling tinggi diantara negara negara lain di Asia Tenggara, hal ini diharapkan bisa menarik para investor asing, sehingga mereka tertarik untuk menanamkan modalnya di Indonesia. Dukungan kemudahan persyaratan dan birokrasi sangat dibutuhkan dalam upaya meningkatkan investasi di Indonesia.

Sebelum melakukan pengujian hipotesis menggunakan regresi data panel, peneliti terlebih dahulu melakukan pengujian mengenai asumsi klasik. Ada 4 pengujian yang harus dilakukan, sebagai berikut:

\section{Teknik Analisis Data}

\section{Uji F}

a. Merumuskan hipotesis

Ho: $\beta_{1}, \beta_{2}=0$

Ha: minimal satu koefisien $\beta_{1}$ atau $\beta_{2} \neq 0$

b. Menentukan Level of Significance ( $\alpha$ ) 
Menentukan tingkat signifikansi $(\alpha)$ sebesar 5\% dengan tingkat kepercayaan sebesar 95\%.

c.Membandingkan nilai probabilitas $F_{\text {hitung }}(p)$ dengan tingkat signifikansi $(\alpha)$.

Menentukan kriteria pengujian sebagai berikut:

Ho diterima jika nilai probabilitas $>\alpha(0,05)$

Ho ditolak jika nilai probabilitas $\leq \alpha(0,05)$

a. Menarik kesimpulan

Menerima Ho, berarti bahwa variabel inflasi dan suku bunga secara simultan tidak berpengaruh terhadap kurs valuta asing. Menolak Ho dan menerima Ha, berarti bahwa variabel inflasi dan suku bunga secara simultan berpengaruh terhadap kurs valuta asing

Tabel 4. Hasil Uji F

\begin{tabular}{|l|l|r|r|c|c|c|}
\hline \multicolumn{2}{|l|}{ Model } & $\begin{array}{c}\text { Sum of } \\
\text { Squares }\end{array}$ & Df & $\begin{array}{c}\text { Mean } \\
\text { Square }\end{array}$ & F & Sig. \\
\hline \multirow{3}{*}{1} & Regression & $2,715 \mathrm{E}+09$ & 4 & 678633655 & 9412,744 &, $000^{\mathrm{b}}$ \\
\cline { 2 - 7 } & Residual & 7426024,6 & 103 & 72097,326 & & \\
\cline { 2 - 7 } & Total & $2,722 \mathrm{E}+09$ & 107 & & & \\
\hline
\end{tabular}

Sumber: Data diolah

Berdasarkan tabel 4 nilai probabilitas $F_{\text {hitung }}$ sebesar 0,000 lebih kecil dari tingkat signifikansi $(\alpha)$ sebesar 0,05

\section{d. Mengambil kesimpulan}

Nilai probabilitas variabel independen sebesar 0,000 lebih kecil dari tingkat signifikan $(\alpha)$ sebesar 0,05 maka dapat disimpulkan bahwa Ho ditolak, yang berarti variabel inflasi dan suku bunga secara simultan berpengaruh terhadap kurs valuta asing.

Tabel 5. Hasil Coeficient of Determination

\begin{tabular}{|r|r|r|r|r|r|}
\hline Model & $\mathrm{R}$ & $\begin{array}{c}\mathrm{R} \\
\text { Square }\end{array}$ & $\begin{array}{c}\text { Adjusted } \\
\mathrm{R} \\
\text { Square }\end{array}$ & $\begin{array}{c}\text { Std. } \\
\text { Error of } \\
\text { the } \\
\text { Estimate }\end{array}$ & $\begin{array}{l}\text { Durbin- } \\
\text { Watson }\end{array}$ \\
\hline 1 & $.982^{\mathrm{a}}$ & .964 & .963 & .66297 & 1.634 \\
\hline
\end{tabular}

Sumber: Data diolah 
Dari tabel 5 dapat disimpulkan bahwa variabel prediktor dapat memprediksi atau menjelaskan variabel terikat atau variabel respon $\mathrm{R}^{2}$ (Adjusted $\mathrm{R}$ Square) sebesar 0,963 atau 96,3\%. Hal ini berarti bahwa variabel inflasi dan suku bunga mampu mempengaruhi tingkat kurs valuta asing secara bersama-sama sebesar 96,3\%, sedangkan sisanya sebesar 3,7\% dipengaruhi oleh variabel lain.

\section{Regresi Data Panel}

Untuk melihat pengaruh variabel independen terhadap variabel dependen digunakan analisis regresi data panel dengan pendekatan Fixed Effect Model. Model analisis regresi data panel yang digunakan dalam melakukan pengujian terhadap hipotesis diformulasikan sebagai berikut:

$$
\text { KURS }=\alpha_{1}+\alpha_{2} D_{2 i}+\alpha_{3} D_{3 i}+\alpha_{4} D_{4 i}+\beta_{1} I N F+\beta_{2} S B+e
$$

\section{Keterangan :}

$\alpha_{1}$ : $\quad$ Intersep (konstanta) negara pembanding

$\mathrm{D}_{2} \ldots \mathrm{D}_{4}$ : Dummy Variabel untuk 3 negara sedangkan sisanya, satu negara $\left(D_{1}\right)$ dipakai sebagai sebagai negara pembanding (bebas untuk memilih negara mana sebagai negara pembanding)

$\beta_{1}-\beta_{2}: \quad$ Koefisien Regresi

KURS: Nilai Tukar Mata Uang

INF : Inflasi

SB : Suku Bunga

e: $\quad$ Error Term

Analisis regresi data panel adalah regresi dengan data yang memiliki dimensi waktu dan dimensi ruang. Manfaat digunakannya regresi data panel adalah dapat mengakomodasi karakteristik antar negara yang berbeda, selain itu juga dapat mempelajari kedinamisan data. Hasil regresi data panel disajikan pada tabel 6

Tabel 6. Hasil Regresi Data Panel

\begin{tabular}{|c|c|c|c|c|c|c|}
\hline & \multirow{2}{*}{ Model } & \multicolumn{2}{|c|}{$\begin{array}{c}\text { Unstandardized } \\
\text { Coefficients }\end{array}$} & \multirow{2}{*}{$\begin{array}{c}\begin{array}{c}\text { Standardized } \\
\text { Coefficients }\end{array} \\
\text { Beta }\end{array}$} & \multirow[t]{2}{*}{$\mathrm{t}$} & \multirow[t]{2}{*}{ Sig. } \\
\hline & & B & $\begin{array}{l}\text { Std. } \\
\text { Error }\end{array}$ & & & \\
\hline \multirow[t]{5}{*}{1} & (Constant) & $-3784,114$ & 916,812 & & $-4,127$ & 0 \\
\hline & INFLASI & 96,909 & 8,891 & 0,119 & 10,9 & 0 \\
\hline & SB & 406,977 & 40,406 & 0,173 & 10,072 & 0 \\
\hline & $\mathrm{D} 2$ & $-7851,82$ & 142,412 & $-0,737$ & $-55,135$ & 0 \\
\hline & D3 & $-7840,833$ & 157,419 & $-0,736$ & $-49,809$ & 0 \\
\hline
\end{tabular}

Sumber: Data diolah 
Analisis regresi data panel yang dihasilkan dengan bantuan SPSS 23.0 for windows, diperoleh persamaan regresinya sebagai berikut:

$$
\text { KURS = } \quad-3784,114+96,909 \text { INF }+406,977 \text { SB }
$$

Maknanya adalah:

\section{Indonesia}

KURS $=-3784,114+96,909 \mathrm{INF}+406,977 \mathrm{SB}$

\section{Malaysia}

$$
\begin{aligned}
\text { KURS }=\quad & (-3784,114-7851,820)+96,909 \mathrm{INF}+406,977 \mathrm{SB} \\
& -11635,934+96,909 \mathrm{INF}+406,977 \mathrm{SB}
\end{aligned}
$$

\section{Thailand}

$$
\begin{aligned}
\text { KURS }= & (-3784,114-7840,833)+96,909 \mathrm{INF}+406,977 \mathrm{SB} \\
& -11624,947+96,909 \mathrm{INF}+406,977 \mathrm{SB}
\end{aligned}
$$

Perbedaan konstanta (intercept) untuk masing-masing negara ini dianggap wajar karena setiap negara mempunyai faktor yang berbeda-beda dalam menentukan tingkat kurs valuta asing. Dari hasil uji di atas terlihat bahwa Indonesia mengalami depresiasi paling besar dibandingkan Malaysia dan Thailand. Hal ini bisa dilihat dari nilai konstanta negara Indonesia paling besar.

\section{a. Uji t}

a. Pengujian Hipotesis Pertama

1) Penentuan Formulasi Hipotesis

$\mathrm{Ho}_{1}: \beta_{1}=0$ Inflasi tidak berpengaruh terhadap tingkat kurs valuta asing

$\mathrm{Ha}_{1}: \beta_{1} \neq 0$ Inflasi berpengaruh terhadap tingkat kurs valuta asing

2) Menentukan tingkat signifikansi $(\alpha)$ sebesar 5\% dengan derajat kebebasan (df) n-k-1=

$108-3-1=104$.

3) Dari hasil analisis diperoleh nilai probabilitas (p) sebesar $0,000<(\alpha)$ 0,05 atau $\mathrm{p}<0,05$ 
4) Mengambil kesimpulan

Karena nilai probabilitas sebesar 0,000 lebih kecil dari tingkat signifikansi $(\alpha)$ sebesar 0,05 , maka dapat disimpulkan Ho ditolak. Artinya inflasi berpengaruh terhadap tingkat kurs valuta asing

b. Pengujian Hipotesis Kedua

1). Penentuan Formulasi Hipotesis

Ho1: $\beta_{2}=0$ Suku Bunga tidak berpengaruh terhadap tingkat kurs valuta asing

$\mathrm{Ha}_{1}: \beta_{2} \neq 0 \quad$ Suku Bunga berpengaruh terhadap tingkat kurs valuta asing

2). Menentukan tingkat signifikansi $(\alpha)$ sebesar 5\% dengan derajat kebebasan (df) n-k-1= 108-3-1= 104

3). Dari hasil analisis diperoleh nilai probabilitas (p) sebesar $0,000<$ (a) 0,05 atau $\mathrm{p}<0,05$

4). Mengambil kesimpulan

Karena nilai probabilitas sebesar 0,000 lebih kecil dari tingkat signifikansi $(\alpha)$ sebesar 0,05, maka dapat disimpulkan Ho ditolak. Artinya suku bunga berpengaruh terhadap tingkat kurs valuta asing

\section{PEMBAHASAN}

Berdasarkan hasil uji asumsi klasik, model regresi data panel memenuhi uji asumsi klasik yang terdiri dari uji normalitas, uji multikolinieritas, uji heteroskedastisitas, dan uji autokorelasi. Dari data yang telah diperoleh selama periode pengamatan terlihat kecenderungan perkembangan variabel mengalami fluktuasi. Hal ini disebabkan karena kondisi perekonomian yang tidak stabil selama beberapa tahun terakhir. Hasil analisis data statistik terhadap 3 negara di Asia Tenggara periode 2012-2014 menunjukkan bahwa inflasi dan suku bunga secara simultan berpengaruh terhadap tingkat kurs valuta asing.

Inflasi merupakan kecenderungan harga untuk menaik secara umum dan terus menerus. Hasil penelitian ini menunjukkan bahwa inflasi berpengaruh positif dan signifikan terhadap kurs valuta asing. Seperti telah dijelaskan diawal jika harga barang-barang dalam suatu negara meningkat, relatif terhadap harga barang-barang 
dari luar negeri maka akan mengakibatkan nilai tukar mata uang negara tersebut terdepresiasi. Jika suatu negara menjadi lebih produktif dibandingkan negara lain, harga barang-barang di dalam negeri akan turun. Hal ini akan mengakibatkan peningkatan permintaan akan barang-barang dalam negeri dan selanjutnya nilai tukar mata uang negara tersebut mengalami apresiasi.

Meningkatnya permintaan impor akan mengakibatkan permintaan mata uang asing untuk pembayaran barang-barang impor menjadi semakin tinggi karena harga barang impor juga meningkat karena inflasi yang terjadi di negara tersebut. Hal ini akan berdampak pada semakin meningkatnya permintaan mata uang asing untuk pembayaran barang impor tersebut. Akibat selanjutnya mata uang negara tersebut akan mengalami depresiasi. Hasil penelitian ini mendukung teori Puchasing Power Parity (PPP), yang menyebutkan bahwa dalam jangka panjang jika harga barangbarang di Indonesia meningkat, relatif terhadap harga barang-barang dari luar negeri maka akan mengakibatkan Rupiah cenderung terdepresiasi. Selain itu juga mendukung penelitian yang dilakukan oleh Canales \& Karl (2004) yang menyebutkan bahwa volatilitas kurs valuta asing meningkat di negara yang memiliki tingkat inflasi tinggi dan sistem kurs bebas (flexible exchange rate).

Di sisi lain, suku bunga merupakan harga dari uang. Jika suku bunga dalam negeri relatif lebih tinggi dibandingkan negara lain, maka nilai mata uang negara tersebut akan mengalami apresiasi. Hal ini disebabkan karena suku bunga yang tinggi akan menarik bagi para investor asing, sehingga mereka tertarik untuk menanamkan modalnya di negara tersebut, sehingga permintaan mata uang negara tersebut meningkat dan selanjutnya akan mengalami apresiasi. Akan tetapi hasil penelitian ini menunjukkan bahwa suku bunga berpengaruh positif terhadap kurs valuta asing. Hal ini diduga disebabkan kebijakan pemerintah yang cenderung menaikkan tingkat suku bunga untuk mengantisipasi adanya faktor non ekonomi yang mempengaruhi fluktuasi kurs valuta asing seperti situasi politik suatu negara, krisis ekonomi global yang dampaknya meluas hampir ke seluruh negara di dunia. Hasil penelitian ini mendukung penelitian yang dilakukan Ulfa (2012).

\section{PENUTUP}

Fluktuasi kurs mata uang sejumlah negara Asia akhir-akhir ini sangat berdampak pada kondisi perekonomian dalam negeri suatu negara. Penelitian ini 
ingin melihat faktor-faktor apa yang mempengaruhi kurs valuta asing. Dari hasil pengujian diketahui bahwa inflasi dan suku bunga merupakan faktor yang mempengaruhi kurs valuta asing, terlihat dari hasil uji fixed effect model yang menunjukkan inflasi berpengaruh positif dan signifikan terhadap kurs valuta asing. Hal ini ditunjukkan dari nilai $(p)$ sebesar $0,000<(\alpha)$ 0,05. Seperti sudah dijelaskan pada landasan teori bahwa jika harga barang-barang di Indonesia meningkat, relatif terhadap harga barang-barang dari luar negeri maka akan mengakibatkan mata uang suatu negara cenderung terdepresiasi. Sedangkan untuk suku bunga, hasil penelitian ini menunjukkan bahwa suku bunga berpengaruh positif terhadap kurs valuta asing. Pada kondisi saat ini suku bunga yang semakin tinggi menunjukkan bahwa kondisi sektor keuangan dan perbankan sedang mengalami tekanan, hal ini akan mempengaruhi persepsi masyarakat internasional terhadap kemampuan negara tersebut, dampak selanjutnya adalah mata uang negara tersebut mengalami depresiasi. Selain itu diduga ada faktor non ekonomi yang turut mempengaruhi fluktuasi kurs valuta asing. Hasil penelitian juga menunjukkan bahwa negara Indonesia mengalami depresiasi yang paling besar diantara negara Malaysia dan Thailand.

\section{Saran}

Berdasarkan hasil penelitian di atas, agar dapat diupayakan kestabilan nilai kurs valuta asing, maka penulis mengajukan saran-saran sebagai berikut:

1. Pemerintah tetap menjaga kondisi inflasi yang wajar agar kurs mata uang suatu negara terhadap mata uang asing tidak terdepresiasi terlalu dalam.

2. Menerapkan suku bunga yang kompetitif untuk merangsang tingkat investasi dan menarik modal baik domestik maupun asing masuk ke dalam negeri. Dalam hal ini perlu didukung iklim usaha yang kondusif.

Usulan bagi penelitian selanjutnya sebagai berikut:

1. Diharapkan peneliti selanjutnya menambah variabel lain yang juga dapat mempengaruhi fluktuasi kurs valuta asing.

2. Menggunakan data yang terbaru agar lebih up to date, dan saat kondisi perekonomian stabil.

3. Menambah jumlah sampel agar bisa melihat perbedaan karakteristik negara-negara di Asia Tenggara. 


\section{DAFTAR REFERENSI}

Andini, Della, dkk .2014. "Masyarakat Ekonomi ASEAN dan Mata Uang Tunggal ASEAN". Makalah. Universitas Brawijaya Malang

Atmadja, Adwin Surya .2001. "Free Floating Exchange Rate System dan Penerapannya pada Kebijaksanaan Ekonomi di Negara yang Berperekonomian Kecil dan Terbuka”. Jurnal Akuntansi \& Keuangan. Vol. 3, No. 1, Mei 2001: $18-29$.

Baskoro, Arya. 2014. "Peluang, Tantangan, dan Risiko Bagi Indonesia Dengan Adanya Masyarakat Ekonomi ASEAN, Center for Risk Management Studies". http://crmsindonesia.org/node/624.

Benigno, Gianluca and Benigno, Pierpaolo, 2000, "Monetary Policy Rules and the Exchange Rate", Working Papers Series, University of California at Barkeley and Princetown University

Camarazza, Francesco and Jahangir Aziz. 1997. "Fixed or Flexible ?- Getting The Exchange Rate Right in the 1990s", World Economic Outlook, Ch 4.

Erawati, Neny dan Llewelyn, Richard. 2002. "Analisa Pergerakan Suku Bunga dan Laju Ekspektasi Inflasi Untuk Menentukan Kebijakan Moneter di Indonesia". Jurnal Manajemen \& Kewirausahaan, Vol. 4, No. 2, September 2002: 98 - 107

Ghozali, Imam dan John Castellan. 2006. Statistik non-Parametrik: Teori dan Aplikasi dengan Program SPSS. UNDIP, Semarang.

Gujarati, Damodar N. 2008. Basic Econometrics $4^{\text {th }}$ Ed. Mc. Graw Hill.

Hasan, Iqbal. 2004. Analisis Data Penelitian dengan Statistik. PT Bumi Aksara, Jakarta.

Hew, Denis and Hadi Soesastro, "Realizing the ASEAN Economic Community by 2020”, ASEAN Economic Bulletin, Vol.20 No 3: 292-296

Kriljenko, Jorge Canales and Habermeier, Karl 2004, "Structural Factors Affecting Exchange Rate Volatility: A Cross-Section Study", IMF Working Paper, No. 04/147, (Washington: International Monetary Fund)

Latif, Syahid. 2014. "Kurs Rupiah Lebih Perkasa dibandingkan Ringgit Malaysia". http://bisnis.liputan6.com/read/802418/kurs-rupiah-lebih-perkasadibandingkan-ringgit-malaysia"

Miskhin, Frederik S. 2011, The Economic of Money, Banking and Financial Market, 7 th Ed Pearson Addison Wesley. 
Mustafa, Asam. 2005. "The Role of the International Monetary Fund in 1997 Global Financial Crises". Uinversity of phoenix; Washington State University; Walden University; Westwood College; Management Development Institute of Singapore; American Center for Education.

Sugiyono. 2009. Metode Penelitian Bisnis. Alfabeta, Bandung.

Tripathi, Vanita, Seth, Ritika, and Bhandari, Varun . 2012. "On Dynamic Relationship between Foreign Direct Investment (FDI) and Macro-Economic Factors: The Indian Experience", University of New Delhi India

Ulfa, Siti Aminah. 2012. "Pengaruh Jumlah Uang Beredar (JUB), Suku Bunga Sertifikat Bank Indonesia (SBI), Impor, Ekspor terhadap Kurs Rupiah/Dollar Amerika Serikat Periode Januari 2006 sampai Maret 2010". Economics Development Analysis Journal. http://journal.unnes.ac.id/sju/index.php/edaj

Yanxiang Gu, Anthony. 2009. "Real Exchange Rate Behavior Under Peg: Evidence from the Chinese RMB and Malaysian MYR" Review of Pacific Basin Financial Markets and Policies, Vol. 12, No. 1, pp. 141-158, 2009

Zarei*,1, M. Ariff, S.H. Law, and A.M. Nassir, "What Factors Determine Exchange Rates? Evidence from Developed and Emerging Economies" Manuscript for World Finance Conference, July 2016

. 2013. "Pengaruh Fluktuasi Mata Uang pada Perekonomian".

"nformasiforex.com/pengaruh-fluktuasi-mata-uang-pada-perekonomian/ http://ardra.biz/ekonomi/valuta-asing/supply-dan-demand-valuta-asing/ http://www.slideshare.net/nugrohosbm/teori-penentuan-kurs-valutaasinghttps://bugiskha.wordpress.com/2012/04/14/teori-teori-suku-bunga/ http://www.dw.com/id/malaysia-liberalisasi-ekonominya/a-4445437 